\title{
Fungi that cause rot in bunches of grape identified in adult fruit flies (Anastrepha fraterculus) (Diptera: Tephritidae)
}

\author{
Ruben Machota Jr. ${ }^{1 *}$, Lígia C. Bortoli ${ }^{1}$, Marcos Botton², and Anderson D. Grützmacher ${ }^{1}$
}

\begin{abstract}
Anastrepha fraterculus (Wiedemann) is the main species of frugivorous insect that damages berries of table grape (Vitis vinifera L.) in Southern Brazil. This study was conducted to isolate and identify the fungi associated with bunch rot present in the body of adults of A. fraterculus collected in a commercial vineyard. From January to February 2011, adults of $A$. fraterculus were collected from a commercial vineyard of green grapes using adapted McPhail traps. In laboratory, flies bodies were divided into four parts (head, legs, wings, and ovipositor) in Petri dishes with PDA medium to evaluate microorganisms associated. Six adult females of $A$. fraterculus collected in the field were also analyzed in a scanning electron microscope (SEM) to identify spores of fungi. Phytopathogenic microorganisms were found in all sectioned parts. Fungal spores were recorded adhered to the body of adult females of A. fraterculus. The main species of fungi found in the body parts of A. fraterculus were Cladosporium spp. (20.2\% of the obtained colonies), Botrytis cinerea Pers. (12.9\%), Colletotrichum spp. (10.1\%), Penicillium spp. (10.1\%), Fusarium spp. (7.7\%), followed by Rhizopus spp., Trichoderma spp. and Aspergillus spp., suggesting that the insect can serve as a mechanical vector of spores increasing damage in the vineyards.
\end{abstract}

Key words: Botrytis cinerea, grape diseases, Vitis vinifera.

\section{INTRODUCTION}

In the South region of Brazil, the South American fruit fly Anastrepha fraterculus (Wiedemann, 1830) (Diptera: Tephritidae) has been the main plague associated to cultivation of fine table grapes (Vitis vinifera L.) (Formolo et al., 2011; Zart et al., 2011). The damage is caused both by females that punch holes in the berries during oviposition, and by the larvae that damage the pulp by feeding on it (Botton et al., 2003; Zart et al., 2010). The injuries caused by the oviposition cause the premature fall of the berries (Zart et al., 2011) and may also become an entranceway to pathogens (Engelbrecht et al., 2004; Sela et al., 2005).

Spore dispersal and aid in the penetration by phytopathogens by insects has been little considered in the handling of fungal diseases (Pirozynski and Malloch, 1988). In apple growing, an increased incidence of bitter rot caused by fungus Glomerella cingulata (Stoneman) Spauld. \& H. Schrenk in fruits, when associated to

${ }^{1}$ Universidade Federal de Pelotas (UFPel), Faculdade de Agronomia Eliseu Maciel (FAEM) Fitossanidade, PO Box 354, 96010-900, Pelotas, Rio Grande do Sul, Brasil.

*Corresponding author(ruben_soad@yahoo.com.br).

${ }^{2}$ Empresa Brasileira de Pesquisa Agropecuária Embrapa, Embrapa Uva e Vinho, PO Box 130, 95700-000, Bento Gonçalves, Rio Grande do Sul, Brazil.

Received: 29 September 2012.

Accepted: 3 February 2013.

doi:10.4067/S0718-58392013000200018. injuries caused by $A$. fraterculus during oviposition (Berton et al., 2005). Corroborating these results, Santos et al. (2008) have shown that the canker caused by the fungus Botryosphaeria dothidea (Moug.) Ces. \& De Not. was also more incident in apple fruits due to oviposition of A.fraterculus when compared to artificial injuries.

The use of synthetic fungicides is the main handling strategy regarding the rot of bunches and other fungal diseases in vine growing (Chavarria and Santos, 2009). Although it is assumed that insects such as A.fraterculus may act as phytopathogens dispersal agents in vineyards (Engelbrecht et al., 2004), little attention has been given to this factor. Information on the interaction between insects and pathogens, mainly as regards table grapes, has allowed the phytosanitary handling of vineyards, rationalizing the use of agrochemicals (Formolo et al., 2011).

Thus, this work aimed at identifying phytopathogenic fungi that cause rot in bunches of grapes, present in the bodies of adult $A$. fraterculus.

\section{MATERIALS AND METHODS}

A commercial vineyard of fine white table grape 'Italia', located in Caxias do Sul $\left(29^{\circ} 14^{\prime} \mathrm{S}\right.$; 51 $51^{\circ} 14^{\prime} \mathrm{W}$; $630 \mathrm{~m}$ a.s.1.), Rio Grande do Sul, Brazil, was selected for the experiment. The vineyard was planted in 2006, with row spacing of $3.0 \times 1.5 \mathrm{~m}$, with Paulsen 1103 rootstock, in an area of 0.42 ha $(60 \times 70 \mathrm{~m})$, planted on Y system under transparent and plastic waterproofed polyethylene 
covering (160 $\mu \mathrm{m}$ thickness and $2.70 \mathrm{~m}$ width). The vineyard is bordered by other orchards such as persimmon trees Diospyros kaki Thunb., peach trees Prunus persica (L.) Batsch, pitanga trees Eugenia uniflora L., plum trees Prunus domestica L., araça trees Psidium cattleyanum Sabine and orange trees Citrus sinensis (L.) Osbeck. The vineyard was chosen for the work due to the history of infestation with A. fraterculus.

On 28 January, and 2, 10, and 23 February 2011 (period of maturation of the grapevine) six McPhail-type traps were installed baited with hydrolyzed protein (Bio Anastrepha $^{\circledR}$ 5\%, BioControle, Indaiatuba, São Paulo, Brazil) in equidistant distribution in the vineyard, each 15 $\mathrm{m}$. Traps were rotated on each evaluation date to cover the whole area. Each trap was adapted for the collection of adults of $A$. fraterculus by placing in its interior a shading screen (Sombrite ${ }^{\circledR}$ 1006, Equipesca, Campinas, São Paulo, Brazil), cut in a circular shape (15 cm diameter), with a $5 \mathrm{~cm}$ hole punched to its center, connected in order to hinder the contact of insects captured with the attractive solution, and thus prevent the contamination of the flies with the attractive solution (Figure 1).
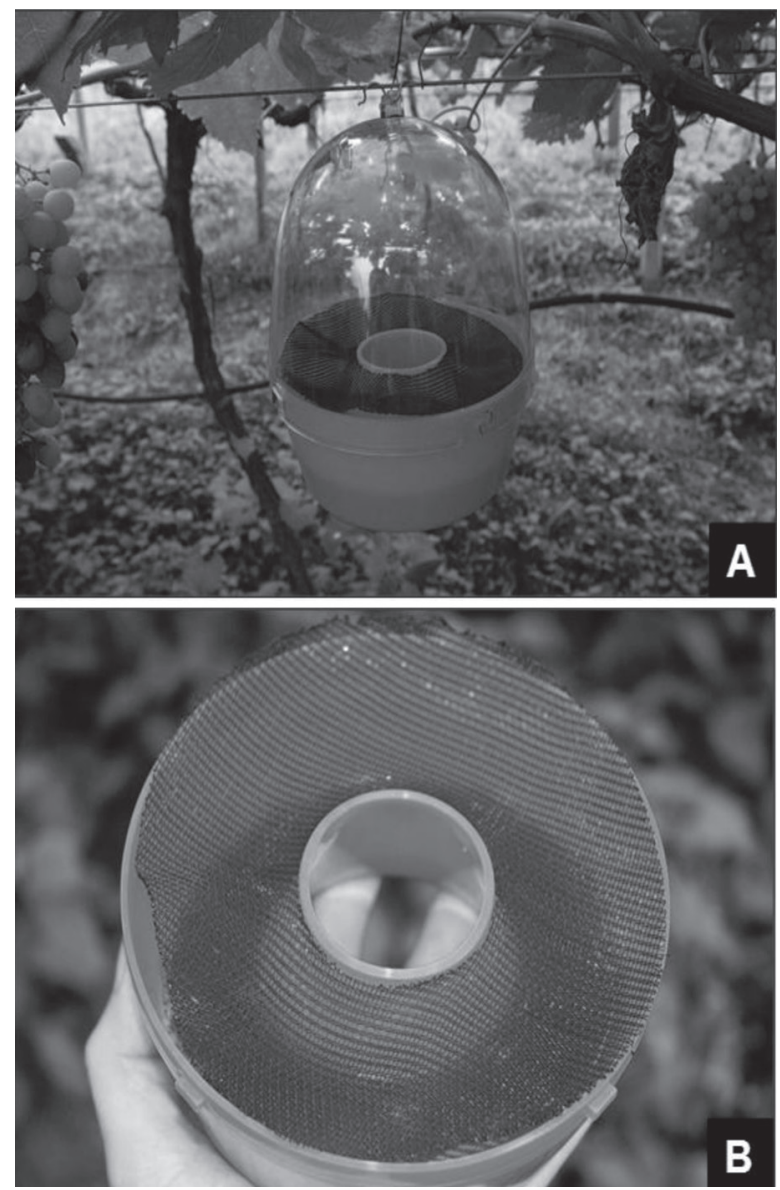

Figure 1. McPhail trap baited with hydrolyzed protein (BioAnastrepha ${ }^{\circledR}, 5 \%$ ) used for the capture of adults of Anastrepha fraterculus. (A) Placement of trap in the vineyard, and (B) interior of the trap containing the shading screen cut in a round shape.
The installation of traps in each sampling date occurred at 09:00 h, collection of $A$. fraterculus was evaluated each $30 \mathrm{~min}$, and collections were interrupted at 16:00 h. The captured insects were individually removed from traps with the aid of a vacuum mouth, made of a transparent PVC hose $(50 \mathrm{~cm}$ length and $0.7 \mathrm{~cm}$ internal diameter), containing in the medium portion of its interior a voile sieve. Immediately after being individually aspirated the insects were placed in sterilized Petri dishes $(6 \mathrm{~cm}$ diameter), using a fine tip histological tweezers $(12 \mathrm{~cm})$. All the equipment, including the McPhail traps, was changed after each captured fly. The material used in the field was hygienized in laboratory (immersion in $70 \%$ alcohol solution, $1.5 \%$ sodium hypochlorite, and washed in distilled and sterilized water for $1 \mathrm{~min}$ ). The collected insects were brought to the laboratory and within $24 \mathrm{~h}$ maximum they were individually anesthetized with $\mathrm{CO}_{2}$ (for $30 \mathrm{~s}$ ) and separate in four portions: (1) head; (2) legs; (3) wings, and (4) ovipositor. Only the females were used in the experiment; the males were discarded.

The tweezers were disinfested with $70 \%$ alcohol with posterior flaming each time an insect's body part was detached. Each one of the insect's body parts were placed in autoclaved $25 \mathrm{~mL}$ plastic Petri dishes in non-selective PDA medium. Dishes containing culture medium, incubated in growth chambers (model 347 CDG, Fanem, São Paulo, SP, Brazil) at $23{ }^{\circ} \mathrm{C}$ and photophase of $12: 12 \mathrm{~h}$ were used as control.

The isolated colonies of microorganisms were precharacterized through the observation of its morphology through optic microscope (400X, model Axiophot, Carl Zeiss Company, Oberkochen, Baden-Württemberg, Germany) after $8 \mathrm{~d}$, with the aid of identification keys (Barnett and Hunter, 1999). Six adult females of $A$. fraterculus collected in field were visualized in scanning electron microscope (model DMS 940, Carl Zeiss Company, Oberkochen, Baden-Württemberg, Germany) in Laboratory of Immunology and Electron Microscopy of Embrapa Temperate Climate, Pelotas, Rio Grande do Sul, Brazil), prepared according to the methodology described by Azevedo Filho et al. (2008).

The insects collected in the experimental area in monitoring traps during the harvest 2010/2011 were identified according to dichotomous key (Zucchi, 2000).

\section{RESULTS AND DISCUSSION}

In the four evaluations 52 females of A. fraterculus were collected in the traps. The largest amount of adults was collected at the beginning of the afternoon, from 13:00 to 15:00 $\mathrm{h}$. This period coincided with the peak of oviposition of the species (Malavasi et al., 1983). Although the experiment was carried out under protected culture, according to Chavarria et al. (2009) the microclimatic conditions provided by this covering do not affect the collection of adults of A. fraterculus in McPhail traps. 
The traps collected 208 colonies of microorganisms of A. fraterculus. Cladosporium spp. Link (20.2\% of the obtained colonies), Botrytis cinerea Pers. (12.9\%), Colletotrichum spp. (10.1\%), Penicillium spp. (10.1\%), Fusarium spp. (7.7\%), Rhizopus spp. Ehrenb. ex Corda (6.7\%), Trichoderma spp. (3.4\%) and Aspergillus spp. Micheli (2.4\%) were registered in the body of $A$. fraterculus, being that the three first ones, with bigger occurrence, are associated to rot of bunches (Table 1).

In 50 flies (94\% of total captured) it was found at least one phytopathogenic microorganism, indicating the presence of contaminating agents in the insect body. The body parts of A. fraterculus (head, legs, wing, and ovipositor) presented, in at least one dish, the development of more than one fungal colony. Cladosporium spp. and Penicillium spp. occurred simultaneously in $7.2 \%$ of the dishes. The fungi Cladosporium spp., Botrytis cinerea, Fusarium spp., Rhizopus spp., and Aspergillus spp. are the main contaminants present in berries of grapes causing losses from pre-harvest until the processing (Bellí et al., 2004).

The acid rot, whose etiology involves a series of microorganisms, besides leavenings and bacteria as Gluconobacter spp. and Acetobacter spp., includes fungi of the Aspergillus spp., Penicillium spp., Cladosporium spp., and Rhizopus spp. genus (Loureiro and MalfeitoFerreira, 2003) were also found in the body of the captured insects.

Cladosporium spp. was the species of bigger occurrence, being found mainly in the head, wings and ovipositor of A. fraterculus (Table 1). The rot of bunches caused by Cladosporium spp. is characterized by the development of a olive-colored mycelium, frequent in wine grapes 'Cabernet Sauvignon' and 'Carménère', which are harvested later, causing the dehydration of the berries, yield reduction, change of color, aroma and flavor of the wine, also affecting the performance of the leavenings responsible for the fermentation processes (Briceño et al., 2009).
The second pathogen of larger occurrence was $B$. cinerea, mainly in the legs and wing of $A$. fraterculus. This pathogen is one of main responsible for losses in the yield and quality of the fruits, both for table grapes and those destined to processing (Sônego et al., 2005). In relation the dispersion of this pathogen in the vineyards, the vinegar fly Drosophila melanogaster Meigen, 1830 (Diptera: Drosophilidae) has been considered the main dispersal agent (Louis et al., 1996) due to adherence of the insect's corporal surface. In this work, fungal spores were recorded for the first time in A. fraterculus by means of scanning electronic microscopy, making it possible to observe the rounded structures, with average dimensions of $10 \mu \mathrm{m}$ adhered to the body of the flies (Figure 2).

Fungal colonies of Colletotrichum spp. and Penicillium spp. developed in all parts, with prominence for the legs in 4.8 and $5.8 \%$ of the colonies, respectively. None of these pathogens was found in the ovipositor.

Colletotrichum spp. is a pathogen found in the majority of the vineyard regions being responsible for the rot of infected bunches (Sônego et al., 2005) resulting in the processing of inferior quality wines (Meunier and Steel, 2009). Although the injuries caused by adults of $A$. fraterculus in grape berries occurs through the oviposition (Botton et al., 2003; Zart et al. 2011), it is known that the genus Colletotrichum does not need injuries to penetrate in the tissue of the hostess (Alfenas and Mafia, 2007). The presence of the pathogen in the head, legs and wings of $A$. fraterculus indicates that the insect disseminate the pathogen between berries and bunches, even in the absence of injuries.

In this work, the development of colonies of Fusarium spp. was also observed in all the isolated parts of the body of $A$. fraterculus. Works developed by Mikušová et al. (2010) also verified the presence of Fusarium spp. in grape berries, reporting its relation with the production of fumonisin mycotoxin.

Table 1. Microorganisms found in body parts of female adults of Anastrepha fraterculus, collected from a vineyard of table grape 'Italia' in adapted McPhail traps.

\begin{tabular}{|c|c|c|c|c|c|c|c|c|c|}
\hline \multirow{3}{*}{ Microorganism } & \multicolumn{8}{|c|}{ Body parts } & \multirow{3}{*}{$\begin{array}{c}\text { Total of colonies } \\
\text { obtained }-\mathrm{N}^{3}\end{array}$} \\
\hline & \multicolumn{2}{|c|}{ Head } & \multicolumn{2}{|c|}{ Legs } & \multicolumn{2}{|c|}{ Wings } & \multicolumn{2}{|c|}{ Ovipositor } & \\
\hline & $\mathrm{n}^{1}$ & $\%^{2}$ & $\mathrm{n}$ & $\%$ & $\mathrm{n}$ & $\%$ & $\mathrm{n}$ & $\%$ & \\
\hline Aspergillus spp. & -4 & - & 2 & 1.0 & - & - & 3 & 1.4 & 5 \\
\hline Botrytis cinerea & - & - & 14 & 6.7 & 9 & 4.3 & 4 & 1.9 & 27 \\
\hline Cladosporium spp. & 15 & 7.2 & 4 & 1.9 & 12 & 5.8 & 11 & 5.3 & 42 \\
\hline Colletotrichum spp. & 4 & 1.9 & 10 & 4.8 & 7 & 3.4 & - & - & 21 \\
\hline Fusarium spp. & 2 & 1.0 & 1 & 0.5 & 8 & 3.8 & 5 & 2.4 & 16 \\
\hline Penicillium spp. & 5 & 2.4 & 12 & 5.8 & 4 & 1.9 & - & - & 21 \\
\hline Rhizopus spp. & 3 & 1.4 & 2 & 1.0 & 4 & 1.9 & 5 & 2.4 & 14 \\
\hline Trichoderma spp. & - & - & 2 & 1.0 & 2 & 1.0 & 3 & 1.4 & 7 \\
\hline Bacteria & 16 & 7.7 & 6 & 2.9 & 11 & 5.3 & 8 & 3.8 & 41 \\
\hline Yeast & 4 & 1.9 & 3 & 1.4 & 2 & 1.0 & 5 & 2.4 & 14 \\
\hline Total & 49 & 23.6 & 56 & 26.9 & 59 & 28.4 & 44 & 21.1 & 208 \\
\hline
\end{tabular}

${ }^{1} \mathrm{n}$ : number of developed colonies.

2\%: percentage from the total of the 208 colonies recorded.

${ }^{3} \mathrm{~N}$ : total number of colonies obtained per pathogen.

${ }^{4}(-)$ : not observed. 

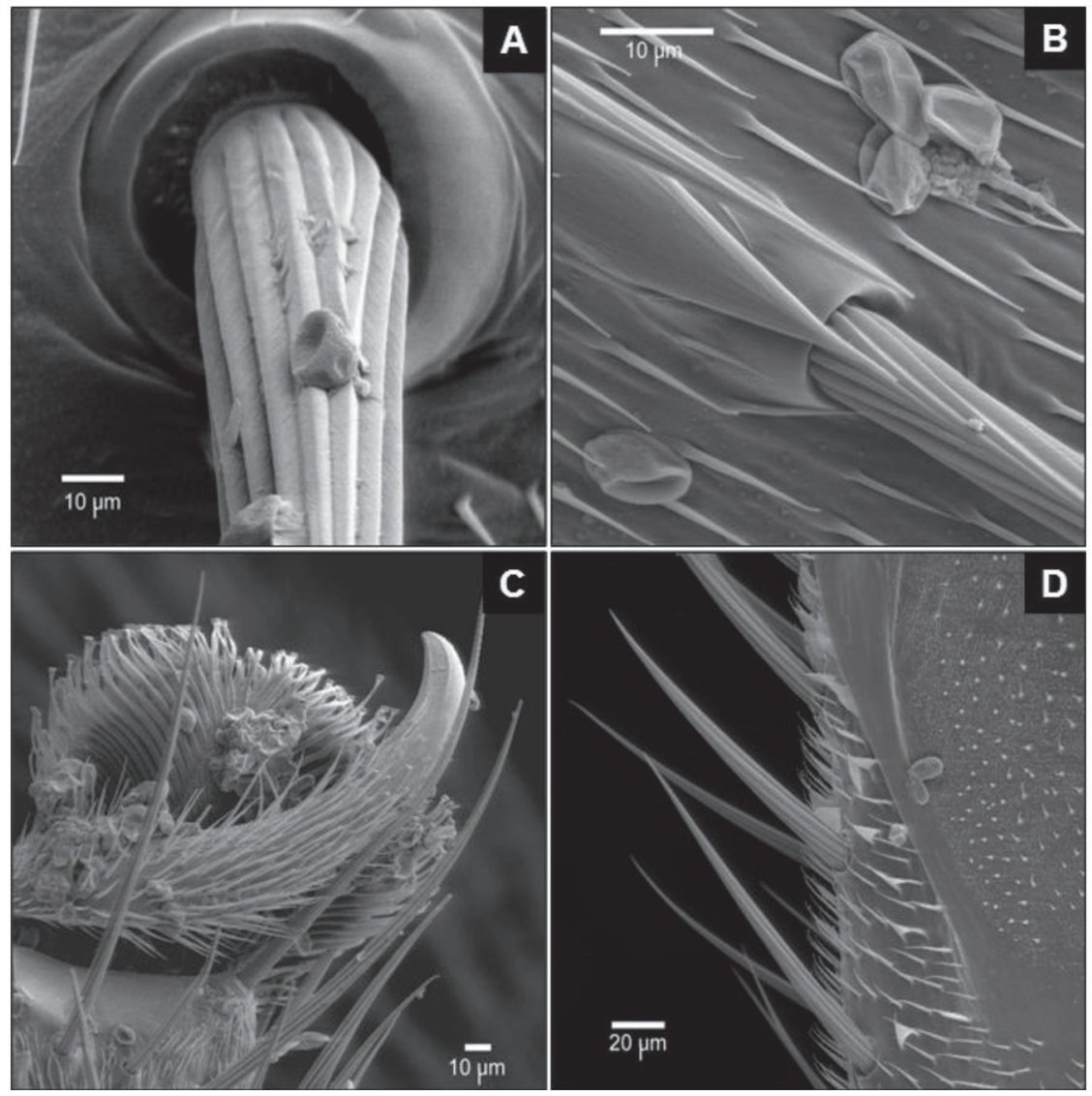

Figure 2. Fungal spores adhered to the body of Anastrepha fraterculus photographed in scanning electron microscope. (A) Front view of an abdominal hair; (B) lateral of the abdomen, (C) final portion of tarsals, and (D) side view of the right pelvis. Bar = scale.

Works by Willison and Dustan (1956) have demonstrated a significant increase of rot caused for Rhizopus nigricans Ehrenb. and Monilinia fructicola (G. Winter) Honey 1928 after infestation by Drosophila spp. in peach. Cayol et al. (1994) used Rhizopus stolonifer (Ehrenb.) Vuill. as model to describe, in laboratory, the potential of transmission of this pathogen by Ceratitis capitata (Wiedemann, 1824) (Diptera: Tephritidae).

Amongst the observed fungal pathogens, Aspergillus spp. presented the lesser occurrence, not being found in the head or in the wings. Works have suggested the influence of fungi belonging to the genus Aspergillus associated to acid rot in vineyards, demonstrating the predominance of Aspergillus carbonarius (Bainier) Thom 1916 and Aspergillus niger Tiegh. 1867 (Kazi et al., 2007). The relation of these pathogens with dipteral is emphasized by Barata et al. (2012) affirming that the development of acid rot in vines depends on the presence of Drosophila spp. in the surface of the grapes, being responsible for the increase of the population of these microorganisms in damaged bunches. The presence of Aspergillus in the body of $A$. fraterculus also includes this species as possible dispersal agent of the pathogen in the vineyards.

Although bacteria and leavenings were not identified in this study, there is a high occurrence of these microorganisms (26.4\% of total colonies obtained), mainly of bacteria, in dishes where heads of flies were deposited. In the grape culture, the leavenings are present in the ground, air, plants or animals, and insects are the main dissemination agents (Mortimer and Polsinelli, 1999). Works by Allen (1931) have suggested the transport of the bacterium Pseudomonas melophthora Allen \& Riker by adults of Rhagoletis pomonella Walsh (Diptera: Tephritidae). The oviposition behavior of fruit-flies comprises some stages, marked by the period of latency (interval between the arrival to the fruit and the beginning of oviposition); recognition of the host; oviposition attempts ("test bites"); oviposition (insertion of the aculeus); dragging and cleaning of the ovipositor (Aluja et al., 2000).

Considering that not all visits to the fruit result in puncture and that not all puncture represents oviposition (Zart et al., 2011), the contact of the insect's body with the berries and the bite of oviposition of A. fraterculus, associated to the presence of reproductive structures of phytopathogens adhered to the ovipositor (aculeus) and legs, will contribute for the increase in the incidence of illnesses in the berries. 
The periods of search or recognition of the host, drag and cleaning of the ovipositor, are characterized by the repeated touch of the lip and aculeus of the ovipositor during the passage on the surface of the fruit, female's displacement on the fruit dragging the aculeus after the oviposition and repeated attrition of the legs on the ovipositor, respectively (Aluja et al., 2000). As some pathogens do not need tissue injuries for penetration (Alfenas and Mafia, 2007) the oviposition behavior of A. fraterculus may have contributed so that the fungal structures were found in different portions of the insect's body. Another probable cause of contamination would be the mating behavior. According to Burk (1973), the mating of the fruit fly can occur on the host. After the mating the legs are used for cleaning of the final portion of the abdomen and ovipositor.

Cladosporium spp. (5.3\%) and bacteria (3.8\%) were the most frequent microorganisms in the ovipositor, whereas $B$. cinerea was observed more frequently on the legs $(6.7 \%)$. In the head, the most frequently observed microorganisms were Cladosporium spp. (7.2\%) and bacteria $(7.7 \%)$.

In search of protein sources for the development of the ovary, reaching the sexual and physiological maturity (Cornelius et al., 2000), secretions and exudates of the plants, nectar, pollen grains, excrements of birds, bacteria, and leavenings become the main food sources used by fruit flies in the nature (Hendrichs and Prokopy, 1994). Tephritidae present four definite forms of alimentary behavior: grazing, suction, bubbling, and regurgitation (Aluja et al., 2000). This last form, predominant in Anastrepha spp., is characterized by the feeding and later deposition of the regurgitated exudate long the host tissue. Thus, the contact of the buccal parts of the collected flies with phytopathogenic microorganisms through feeding in the field in contaminated berries could be another form of acquisition, transport and dissemination of these microorganisms, explaining the fact that $7.7 \%$ of the total bacteria colonies were recorded on the head.

The Tephritidae possess high biotic potential, easiness of dispersion in the environment and ability of adaptation the different hosts (Zart et al., 2011). The presence of a great diversity of hosts in the studied area, with maturation of fruits at different times of the year, favors the establishment and maintenance of the high density of A. fraterculus. In this case, there is also the possibility that raiding populations of adults of $A$. fraterculus acquired phytopathogens in alternative hosts located close to the vineyard, carrying and exhausting them in the grapevine. For these reasons, due to the high losses caused by rot in the bunches caused by these organisms in table grapes (Sônego et al., 2005), the presence of populations of $A$. fraterculus in the culture (Chavarria et al., 2009; Formolo et al., 2011), the injuries caused by oviposition and the development of the larvae in fungi (Zart et al., 2011), besides the forage behavior and feeding habits related to the presence of phytopathogenic microorganisms in the insect's body, strategies for the management of the species must be considered to reduce the incidence of rot in grape bunches.

\section{CONCLUSION}

It may be concluded that adults of $A$. fraterculus transport spores of Cladosporium spp., Botrytis cinerea Pers., Colletotrichum spp. and Penicillium spp. that cause rot in bunches of grapes, increasing the fruit damages in vineyards.

\section{ACKNOWLEDGEMENTS}

The authors thank Mrs. Renata Gava and Mr. Luis Antônio Suita de Castro, research analysts of Laboratory of Plant Pathology of Embrapa Grape \& Wine and Laboratory of Immunology and Electron Microscopy of Embrapa Temperate Climate, respectively, for the aid in laboratory procedures; Mr. Fábio Rossi Cavalcanti and Mr. Lucas da Ressurreição Garrido (Embrapa Grape \& Wine), Mr. Flávio Roberto Mello Garcia (UFPel), and Mr. Marcus André Kurtz Almança (IFRS), for the suggestions during the preparation of the manuscript; and National Council for Scientific and Technological Development (CNPq), for the financial support to this project.

\section{LITERATURE CITED}

Alfenas, A.C., and R.G. Mafia. 2007. Métodos em fitopatologia. 382 p. Editora UFV, Viçosa, Minas Gerais, Brasil.

Allen, T.C. 1931. Bacteria producing rot of apple in association with the apple maggot, Rhagoletis pomonella. Phytopathology 21:338.

Aluja, M., J. Piñero, I. Jácome, F. Diaz-Fleischer, and J. Sivinsk. 2000. Behavior of flies in the Genus Anastrepha (Trypetinae: Toxotrypanini). p. 375-406. In Aluja, M., and A. Norbom (eds.) Fruit flies (Tephritidae): Phylogeny and evolution of behavior CRC Press, Boca Raton, Florida, USA.

Azevedo Filho, W.S. de, L.A.S. de Castro, M. Botton, e D.E. Nava. 2008. Técnicas de preparação de amostras para estudos de insetos com microscópio eletrônico de varredura. Documentos 230. 34 p Embrapa Clima Temperado, Pelotas, Rio Grande do Sul, Brasil.

Barata, A., S.C. Santos, M. Malfeito-Ferreira, and V. Loureiro. 2012. New insights into the ecological interaction between grape berry microorganisms and Drosophila flies during the development of sour rot. Microbial Ecology 64:416-430.

Barnett, H.L., and B.B. Hunter. 1999. Illustrated genera of imperfect fungi. $4^{\text {th }}$ ed. APS Press, St. Paul, Minnesota, USA.

Bellí, N., S. Marín, A. Duaigües, A.J. Ramos, and V. Sanchis. 2004. Ochratoxin A in wines, musts and grape juices from Spain. Journal of the Science of Food and Agriculture 84:591-594.

Berton, O., J.P. dos Santos, and F. Denardi. 2005. Relação entre danos de mosca-das-frutas e a incidência de podridão-amarga em frutos de macieira. 81 p. In Encontro Nacional sobre Fruticultura de Clima Temperado, Fraiburgo. EPAGRI, Estação Experimental de Caçador, Santa Catarina, Brasil.

Botton, M., E.R. Hickel, e S.J. Soria 2003. Pragas. p. 82-105. In Fajardo, T.V.M. (ed.) Uva para processamento: fitossanidade. Embrapa, Brasília, Brasil.

Briceño, E.X., B.A. Latorre, and E. Bordeu. 2009. Effect of Cladosporium rot on the composition and aromatic compounds of red wine. Spanish Journal of Agricultural Research 7:119-128. 
Burk, T. 1973. Behavior ecology of mating in the Caribbean fruit flies, Anastrepha suspensa (Loew) (Diptera: Tephritidae). Florida Entomologist 66:330-344.

Cayol, J.P., R. Causse, C. Louis, and J. Barthes. 1994. Medfly Ceratitis capitata Wiedemann (Dipt., Trypetidae) as a rot vector in a laboratory conditions. Journal Applied Entomology 117:338343.

Chavarria, G., and H.P. dos Santos. 2009. Manejo de videiras sob cultivo protegido. Ciência Rural 39:1917-1924.

Chavarria, G., M. Zart, M. Botton, H.P. dos Santos, and G.A.B. Marodin. 2009. Flutuação populacional de adultos de Anastrepha fraterculus (Wied.) em cultivo protegido e convencional de videira. Revista Brasileira de Fruticultura 31:725-731.

Cornelius, M.L., J.J. Duan, and R.H. Messing. 2000. Volatile host fruit odors as attractants for the Oriental fruit fly (Diptera: Tephritidae). Journal of Economic Entomology 93:93-100.

Engelbrecht, R., G. Holz, and K.L. Pringle. 2004. Occurrence of fruit-decaying fungi on adult male Mediterranean fruit flies (Ceratitis capitata) captured in orchards and adjacent vineyards. South African Journal of Enology and Viticulture 25:48-53.

Formolo, R., L. Rufato, M. Botton, and R. Machota Junior. 2011. Diagnóstico da área cultivada com uva fina de mesa (Vitis vinifera $\mathrm{L}$.) sob cobertura plástica e do manejo de pragas. Revista Brasileira de Fruticultura 33:103-110.

Hendrichs, J., and R.J. Prokopy. 1994. Food foraging behavior of frugivorous fruit flies. p. 37-55. In Calkins, C.O., W. Klassen, and P. Liedo (eds.) Fruit flies and the sterile insect technique. CRC Press, Boca Raton, Florida, USA.

Kazi, B.A., R.W. Emmet, N. Nancarrow, and D.L. Partington. 2007. Berry infection and the development if bunch rot in grapes caused by Aspergillus carbonarius. Plant Pathology 57:301-307.

Louis, C., M. Girard, G. Kuhl, and M. Lopez-Ferber. 1996. Persistence of Botrytis cinerea in its vector Drosophila melanogaster. Phytopathology 86:934-939.

Loureiro, V., and M. Malfeito-Ferreira. 2003. Spoilage yeast in the wine industry. International Journal of Food Microbiology 86:2350 .

Malavasi, A., J.S. Morgante, and R.J. Prokopy. 1983. Distribution and activities of Anastrepha fraterculus (Diptera: Tephritidae) flies on host and nonhost trees. Annals of the Entomological Society of America 76:286-292.
Meunier, M., and C.C. Steel. 2009. Effect of Colletotrichum acutatum ripe rot on the composition and sensory attributes of 'Cabernet Sauvignon' grapes and wine. Australian Journal of Grape and Wine Research 15:223-227.

Mikušová, P., A. Ritieni, G. Juhasová, and A. Srobárová. 2010. Contamination by moulds of grape berries in Slovakia. Food Additives \& Contaminants: Part A 27(5):738-747.

Mortimer, R., and M. Polsinelli. 1999. On the origins of wine yeast. Research in Microbiology 150:199-204.

Pirozynski, K.A., and D.W. Malloch. 1988. Seeds, spores and stomachs: coevolution in seed dispersal mutualisms. p. 227-246. In Pirozynski, K.A., and D.L. Hawksworth (eds.) Coevolution of fungi with plants and animals. Academic Press, New York, USA.

Santos, J.P. dos, A.R. Corrent, O. Berton, L.L. Schwarz, and F. Denardi. 2008. Incidência de podridão-branca em frutos de macieira com e sem ferimentos. Revista Brasileira de Fruticultura 30:118-121.

Sela, S., D. Nestel, R. Pinto, E. Nemny-Lavy, and M. Bar-Joseph. 2005. Mediterranean fruit fly as a potential vector of bacterial pathogens. Applied and Environmental Microbiology 71:40524056.

Sônego, O.R., L. da R. Garrido, and A. Grigoletti Jr. 2005. Principais doenças fúngicas da videira no Sul do Brasil. Circular Técnica 56. 32 p. Embrapa Uva e Vinho, Bento Gonçalves, Rio Grande do Sul, Brasil.

Willison, R.S., and G.G. Dustan. 1956. Fruit flies and fungal wastage in peaches. Canadian Journal of Agricultural Science 36:233-240.

Zart, M., M. Botton, and O.A. Fernandes. 2011. Injúrias causadas por Anastrepha fraterculus (Wiedemann) (Diptera: Tephritidae) em cultivares de videira. Bragantia 70:64-71.

Zart, M., O.A. Fernandes, and M. Botton. 2010. Biology and fertility life table of the South American fruit fly Anastrepha fraterculus on grape. Bulletin of Insectology 63:237-242.

Zucchi, R.A. 2000. Taxonomia. p. 13-24. In Malavasi, A., and R.A. Zucchi (eds.) Moscas-das-frutas de importância econômica no Brasil: conhecimento básico e aplicado. Holos Editora, Ribeirão Preto, São Paulo, Brasil. 